\title{
COMFORT SIMULATION SUPPORTED SKETCH PLAN OPTIMIZATION OF THE UNIVERSITY OF PÉCS, MEDICAL SCHOOL EXTENSION
}

\author{
${ }^{1}$ Dóra Noémi ZETZ ${ }^{*}{ }^{2}$ István KISTELEGDI \\ ${ }^{1}$ Marcel Breuer Doctoral School, Department of Building Structures and Energy Design \\ Institute of Architecture, Faculty of Engineering and Information Technology \\ Boszorkány u. 2, University of Pécs, H-7624 Pécs, Hungary, e-mail: ${ }^{1}$ zetzdora@gmail.com \\ ${ }^{2}$ Department of Building Structures and Energy Design, Institute of Architecture \\ Faculty of Engineering and Information Technology, Boszorkány u. 2, \\ and János Szentágothai Research Center, Ifjúság u. 20, University of Pécs \\ H-7624 Pécs, Hungary, e-mail: ${ }^{2}$ kistelegdisoma@mik.pte.hu
}

Received 30 May 2019; accepted 8 November 2019

\begin{abstract}
During sketch design stage for the new block of the University of Pécs, Medical School comfort and lighting simulations were applied to quantify optimization strategies. Simulation cases about shading possibilities, façade glazing ratios and internal heat storage masses evaluate the impact of illumination, solar gains, loads and heat transmission on visual and thermal comfort. The goal was to select the most favorable comfort, coupled with maximum reduction of investment costs. Concepts represent 14\% (shading), 10\% (reduced wall-window ratio), $11 \%$ (slabs without suspended ceilings), and 17\% (combined wall-window ratio and thermal mass) improvement in thermal comfort performance, and it was proposed for further design.
\end{abstract}

Keywords: Medical school, Sketch plan for optimization, Thermal and daylight simulation, Shading, wall-window ratio, Thermal mass, Thermal and visual comfort, Optimal model

\section{Introduction and research goal}

Within the framework of the Hungarian Modern Cities Program, correlatively to the development of a new theoretical block of the Medical School (MS) of the University of Pécs (PTE) sketch plan decision support with building simulation was desired. Many studies investigate a wide range of diverse building optimization strategies with coupled simulation supported algorithms, whereas advanced investigations focus on building optimization using simulation coupled generative algorithms [1]-[8]. Case studies represent an important field among these optimization studies [9]-[15], providing useful

\footnotetext{
${ }^{*}$ Corresponding Author
} 
knowledge for building development. However, most case studies remain on a general and theoretic level, without real project experiment relation, containing most characteristic practical problems and tasks. In contrast, in common real implemented case study comfort and energy optimisation projects the following boundary conditions are already fixed by the architect: space organisation; functional layout; building body shape and structures; materials. The building shape becomes frequently a more or less complex form with diversely oriented façade surfaces and deep building wings (internal rooms without windows). In addition, multiple construction situations possess proximate neighborhood structures, providing volitional or undesired shading effects on the building to be planned. In this kind of complex solar radiation and shading circumstances, possible optimisation fields are the building envelope's shading, wallwindow ratio (WWR) varieties and working thermal mass. Particular Medical School extension project is one of these typical cases and deal with these issues. The results support not only architectural sketch design stage decisions with simulated building physics performance assessments, but the gained insights also reveal inductive conclusions for large scaled office, lab and education buildings in moderate climate.

The planned building extension includes approx. $12.916 \mathrm{~m}^{2}$ useful floor area with 5 floors. On the basement part there is a parking level, on the ground floor and the 1st floor entrance halls, auditoriums, laboratories, buffet, toilets, on the $2^{\text {nd }}$ and $3^{\text {rd }}$ floor have offices, access control system labs, changing rooms and toilets complete the room program. Based on the customer's demand, the main concept of the building, the horizontal and vertical space organization of the building, the building body shape, the structures, filling and partition structures, as well as the placement of the doors and windows had to be handled as an 'existing' fixed boundary condition.

The purpose of the tests was to determine and compromise the optimum combination of shading technology, WWR, and heat storage mass with special regard to thermal and visual comfort performance.

\section{Methodology}

During the tests, zonal modeling was used, which measures data in a given central node in a zone on an annual basis, in hourly resolution. The energy and climate dynamic building simulations were implemented using the IDA ICE 4.8 software. With the simulations, the following features of the plan have been considered, taking into account the surrounding neighborhood buildings and the orientation. It was necessary to analyze the north-south orientation of the new building, its self-shading, and the shading effect of the old, existing PTE MS block, located on the southern side. Using daylight analysis the needs of additional shading should be determined. At next, it was necessary to examine the various shading solutions of the transparent building envelope structures and to examine whether any shading structures are required or not. In the following step, the most optimal version of the different wall-window ratios of the facades was selected. In addition, the effect of the 'freed' heat storing masses (reinforced concrete slab structures) released by the abandonment of suspended ceilings was analyzed.

In these cases, the following technical content has been quantified, scaled, and interpreted: 
- Thermal comfort during both heating and cooling operation periods (EN 15251);

- Visual comfort, daytime natural illumination strength.

The building physics examinations were carried out in several solar-exposed sample rooms and throughout the complete building. In comparison to the reference model (unshaded, fully glazed facades and suspended ceiling in the interior) typical differences in the thermal comfort assessment were shown in the second floor, south-facing sample rooms, so the results measured there were presented in detail below. Evaluation of the results for the complete building was necessary in the thermal mass investigation case.

\section{Boundary conditions and settings}

The geographical location of the building site, the local climate conditions, the neighborhood, the existing PTE MS building block were taken into account in the thermal simulations. With the help of the Meteonorm 7 climate database annual average profiles can be generated from the nearest meteorological measurement stations in Hungary and neighboring countries. These data is integrated into the thermal model: external air temperature $\left({ }^{\circ} \mathrm{C}\right)$, relative humidity of external air $(\%)$, solar direct radiation $\left(\mathrm{W} / \mathrm{m}^{2}\right)$, and solar diffuse radiation $\left(\mathrm{W} / \mathrm{m}^{2}\right)$, and wind velocity $(\mathrm{m} / \mathrm{s})$, wind direction $\left({ }^{\circ}\right)$ vector coordinates.

The conventional structures of the pillar-frame are made of reinforced concrete slabs, insulated filler walls (Porotherm $30 \mathrm{~N}+\mathrm{F}$ frame ceramic external wall, $16 \mathrm{~cm}$ Rockwool Frontrock MAX-E external thermal insulation). The doors and glazed structures in the façade are designed with three-layer insulated glazing.

Structures' thermal properties (including all relevant layers) according to Hungarian building energy regulation 7/2006 (V.24. TNM, 5.) and 20/2014 BM: ground floor: $U_{\text {floor }}=0.1430 \mathrm{~W} / \mathrm{m}^{2} \mathrm{~K}$, Arcade slab: $U_{\text {arcade salb }}=0.1405 \mathrm{~W} / \mathrm{m}^{2} \mathrm{~K}$, Intermediate slab: $U_{\text {intermediate slab }}=0.0396 \mathrm{~W} / \mathrm{m}^{2} \mathrm{~K}$, Final slab: $U_{\text {final slab }}=0.03378 \mathrm{~W} / \mathrm{m}^{2} \mathrm{~K}$, Exterior wall: $U_{\text {wall }}=0.1582 \mathrm{~W} / \mathrm{m}^{2} \mathrm{~K}$, Exterior cellar wall: $U_{\text {cellar wall }}=0.2004 \mathrm{~W} / \mathrm{m}^{2} \mathrm{~K}$, Glazing structure: $U_{\text {window }}=0.92 \mathrm{~W} / \mathrm{m}^{2} \mathrm{~K}$, External blinds: Schedule 15 April - 15 Oct, shading is drawn when solar radiation level on outside pane exceeds $100 \mathrm{~W} / \mathrm{m}^{2}$. Acc. to Hungarian heating supply period, the chosen cooling and shading schedule is: 15.04. - 15.10.

To produce dynamic thermal simulations, a 3D simulation model was created, consisting of nearly 100 climate zones. Fig. 1 shows the structure of the climate zone model on 3D horizontal sections per level, where the operation and basic settings of the zones have been formulated.

Artificial lighting: In the basic settings of the simulation model, the artificial lighting of the rooms was operated at $12 \mathrm{~lm} / \mathrm{W}$ luminous efficacy and $100 \mathrm{~W}$ electrical powers per lamp. The number of lamps or light sources in the given zone is automatically modeled according to the useful floor area $\left(0.1 \mathrm{pcs} . / \mathrm{m}^{2}\right.$ useful floor area). The artificial lighting system is controlled between 100 and $500 \mathrm{~lx}$ illumination; it switches on below $100 \mathrm{~lx}$ and switches off above the limit value of $500 \mathrm{~lx}$. 
Equipment: Waste heat producing equipment had to be considered in the basic settings in $\mathrm{W} / \mathrm{pcs}$. The equipment power and intensity of operation and timing are modeled on average statistical values [16].

Occupants: 0.1 person $/ \mathrm{m}^{2}$ by default. People using the individual rooms are active at $0-100 \%$ intensity during the day, during the opening hours, simulating real use. The level of activity and clothing of the occupants determines the heat emission (sensitive and latent), which can be given by the met (metabolic rate) value and the clo factor of the clothing (ASHRAE Fundamentals 2017).

Definition of mechanical systems: Considering that the present thermal simulations are specifically intended to help the design of the building and the building envelope in sketch plan phase, so in the simulation calculations central building services systems has been modeled with so-called basic settings.
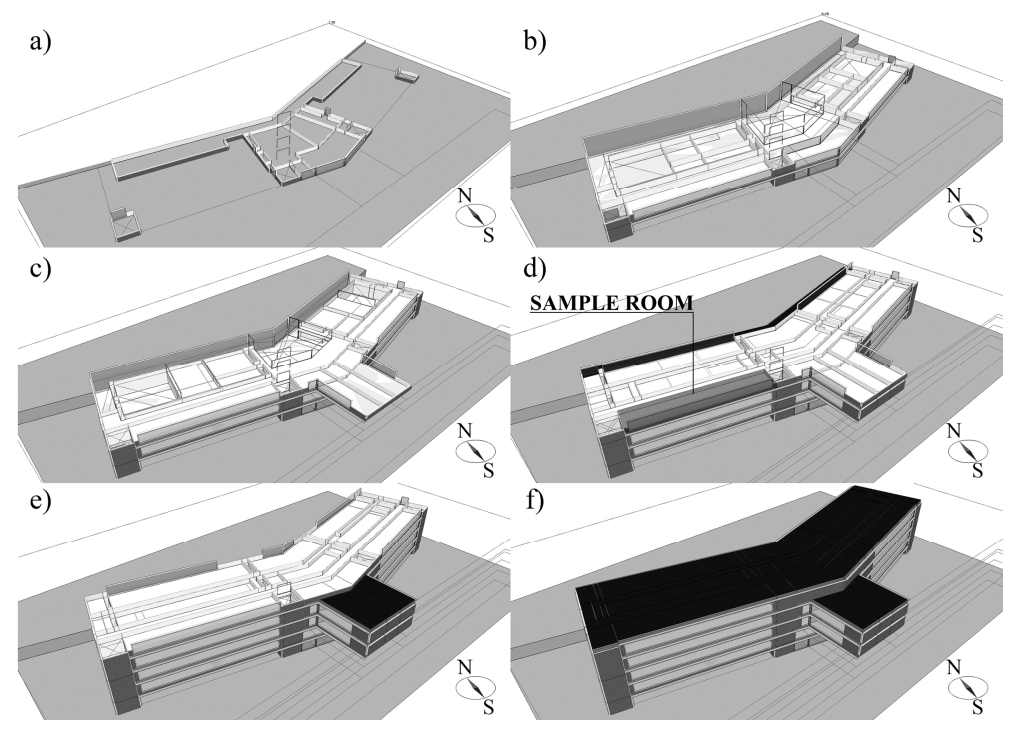

Fig. 1. 3D climate zone simulation model, a) Parking level b) Ground floor,

c) First floor, d) Second floor, with sample room (No. 58.) e) Third floor, f) Roof view

The heating and cooling in the interiors produces indoor comfort based on $21-25^{\circ} \mathrm{C}, 20-80 \%$ relative humidity, $700-1100 \mathrm{ppm}$ level of $\mathrm{CO}_{2}$, and $0.3-7 \mathrm{l} / \mathrm{s} . \mathrm{m}^{2}$ air volume flow set points throughout the year. Based on the floor space, the heat exchanger system consists of heating units $\left(100 \mathrm{~W} / \mathrm{m}^{2}\right)$ and cooling units $\left(200 \mathrm{~W} / \mathrm{m}^{2}\right)$. Air change is ensured by the Air Handling Units (AHU) system with Constant Air Volume (CAV), with $2 \mathrm{l} / \mathrm{sm}^{2}$ supply and exhaust volume flow. Constant (continuous $100 \%$ ventilator intensity) produces a supply air temperature of $16{ }^{\circ} \mathrm{C}$, with heat recovery of $60 \%$ efficiency, $600 \mathrm{~Pa}$ supply and $400 \mathrm{~Pa}$ exhaust ventilator pressure. Heating and cooling of air is done with the help of a heating and cooling registers. The heat generation system is not modeled yet, only the heat transfer system and the AHU registers ensure the needs. 


\section{Daylight analysis}

Due to the orientation of the new building and the shading effect of the existing block from the southern side, firstly, it was necessary to investigate the daylight performance in seasonal and 24-hour resolution, depending on the solar path. Fig. 2 visualizes the new building's southern and northern facades at summer and winter solstice, at different times of the day.
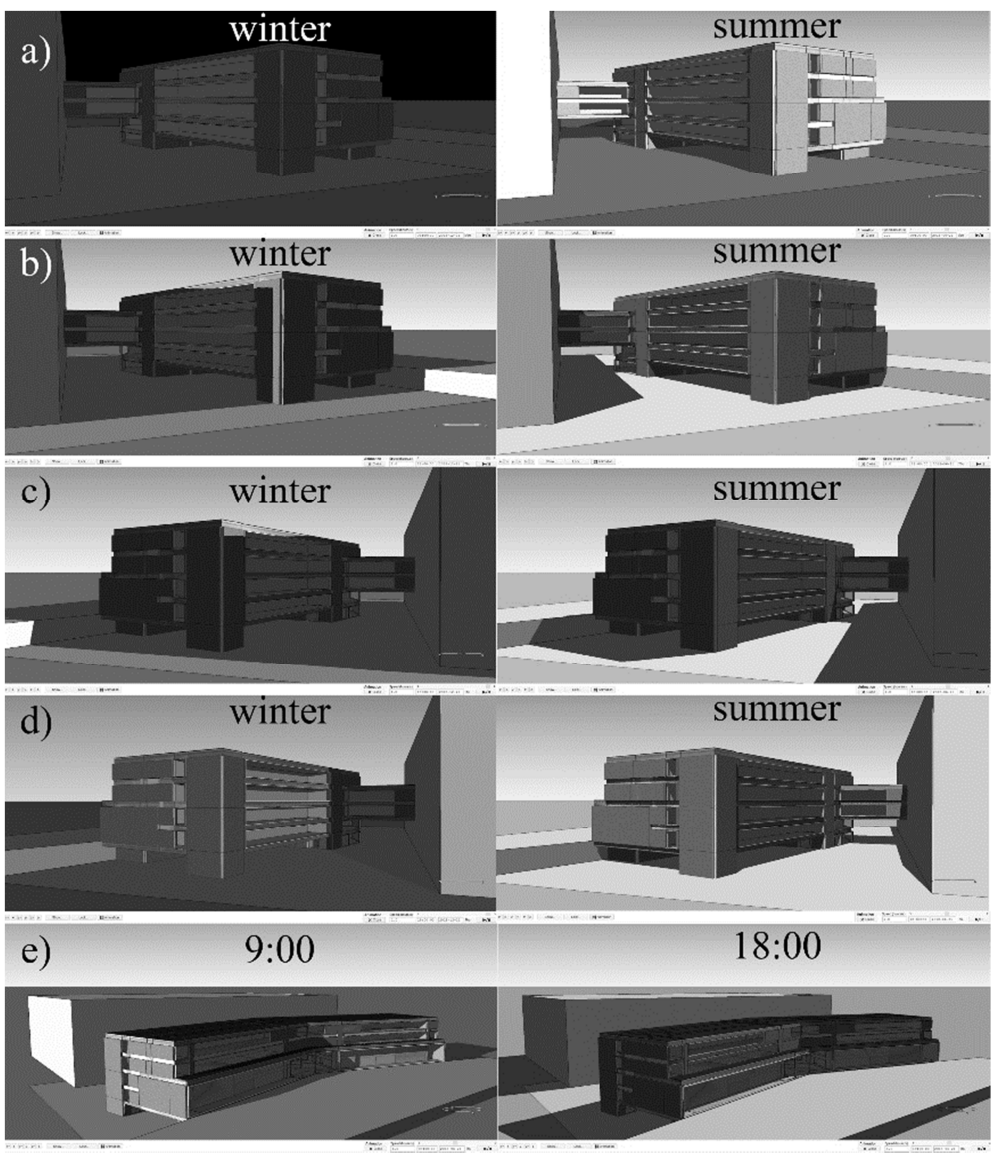

Fig. 2. Daylight analysis, a) facade SE 9:00, b) facade SE 13:00, c) facade S 13:00, d) facade S 18:00, e) façade $\mathrm{N} 21^{\text {th }}$ June, left: 9:00, right: 18:00

In winter, the southeast façade is mostly shaded by the old, existing Medical School, while in summer it is exposed to solar radiation until late afternoon hours. In winter morning the southern facade is shaded, while in the afternoon it is gradually reaching total solar radiation, and in the summer season it is exposed to full solar sunshine in the afternoon hours. The north facades during the winter operating period are virtually continuously shielded due to self-shading. In the summer, the north facade in the 
morning, and the north-west facade in the late-afternoon are exposed to flat-angle sunlight. The 'boomerang' formed building's two wings accommodate same functions and are shaded considerably differently in the changing daytime and seasons' periods. Accordingly, it is necessary to examine whether it is necessary to shield both façades at all, amd, if yes, what kind of shading solution is optimal for the south and southeast façades.

\section{Results and discussion (Case studies)}

In next steps, several case studies including different shading, various Parapet Height (PH) wall-window ratios (WWR), (ezt a roviditest mar egyszer feloldottuk szoban, ezutan mar csak az egyik formatum hasznalhato, azaz a teljes szoveges kiiras vagy a rovidites, ha mindkettot hasznaljuk az redundanciahoz vezet, javitast kerek) and the effect of excluding the Suspended Ceiling (SC) (improvement of thermal mass' cooling effect) were required for testing, analyzing and comparison to determine the optimal model. Table I systemizes the various models. The first five models are with different shading alternatives. Model 1 has $75 \mathrm{~cm}$ deep cantilever in each storey, designed as the reference model by the architect [17]. Further versions are equipped with deeper cantilever (Model 2), and external mobile and fixed shadings (Model 3-5). Further tests (Models 6-8) with various WWR and 'activation' of the thermal mass by erasing the suspended ceiling from the interior (Model 9) provide interesting simulation experiments about the thermal performance development.

Table I

Settings and properties of various models in the investigated cases

\begin{tabular}{|c|c|c|c|c|c|}
\hline \multicolumn{2}{|c|}{ Model descript. } & \multirow{2}{*}{$\begin{array}{c}\text { Shading type } \\
75 \mathrm{~cm} \text { cantilever per } \\
\text { level }\end{array}$} & \multirow{2}{*}{$\begin{array}{c}\text { PH } \\
-\end{array}$} & \multirow{2}{*}{$\begin{array}{c}\text { WWR } \\
\text { Sample } 95 \%, \\
\text { Total } 20.9 \%\end{array}$} & \multirow{2}{*}{$\frac{\text { SC }}{\text { yes }}$} \\
\hline Model 1 & Reference & & & & \\
\hline Model 2 & & $\begin{array}{c}165 \mathrm{~cm} \text { cantilever per } \\
\text { level }\end{array}$ & - & $\begin{array}{l}\text { Sample } 95 \%, \\
\text { Total } 20.9 \%\end{array}$ & yes \\
\hline Model 3 & & $\begin{array}{l}\text { solar controlled } \\
\text { external blinds }\end{array}$ & - & $\begin{array}{l}\text { Sample } 95 \% \text {, } \\
\text { Total } 20.9 \%\end{array}$ & yes \\
\hline Model 4 & $\begin{array}{l}\text { Shading tech. } \\
\text { variants }\end{array}$ & $\begin{array}{l}\text { external fixed vertical } \\
\text { louver blade - all year }\end{array}$ & - & $\begin{array}{l}\text { Sample } 95 \% \\
\text { Total } 20.9 \%\end{array}$ & yes \\
\hline Model 5 & & $\begin{array}{c}\text { external fixed } \\
\text { horizontal louver } \\
\text { blade- all year }\end{array}$ & - & $\begin{array}{l}\text { Sample } 95 \%, \\
\text { Total } 20.9 \%\end{array}$ & yes \\
\hline Model 6 & & $\begin{array}{c}75 \mathrm{~cm} \text { cantilever per } \\
\text { level }\end{array}$ & $\begin{array}{l}60 \\
\mathrm{~cm}\end{array}$ & $\begin{array}{c}\text { Sample } 76 \%, \\
\text { Total } 18.3 \%\end{array}$ & yes \\
\hline Model 7 & WWR variants & $\begin{array}{c}75 \mathrm{~cm} \text { cantilever per } \\
\text { level }\end{array}$ & $\begin{array}{l}90 \\
\mathrm{~cm}\end{array}$ & $\begin{array}{l}\text { Sample } 66.5 \%, \\
\quad \text { Total } 17 \%\end{array}$ & yes \\
\hline Model 8 & & $\begin{array}{c}75 \mathrm{~cm} \text { cantilever per } \\
\text { level }\end{array}$ & $\begin{array}{l}120 \\
\mathrm{~cm}\end{array}$ & $\begin{array}{c}\text { Sample 57\%, } \\
\text { Total } 15.7 \%\end{array}$ & yes \\
\hline Model 9 & 'Active' heat storage & $\begin{array}{c}75 \mathrm{~cm} \text { cantilever per } \\
\text { level }\end{array}$ & - & Total $20.9 \%$ & no \\
\hline
\end{tabular}




\subsection{Thermal comfort}

The chosen sample room for comfort performance evaluation test cases is placed in the $2^{\text {rd }}$ floor, with south-orientation, representing an average main space with average solar radiation gains/loads. The sample space is a unified, simplified office and lab room (No. 58.) with $250 \mathrm{~m}^{2}$ net floor space (Fig. 1). Fig. 3 compares the thermal comfort characteristics of Model 1-9 according to EN 15251 and ISO 7730, showing the classified quantitative distribution of thermal comfort hours in the I (best) and II. (good, $\mathrm{A}+\mathrm{B}$ ) categories in the selected southern office/lab sample room.

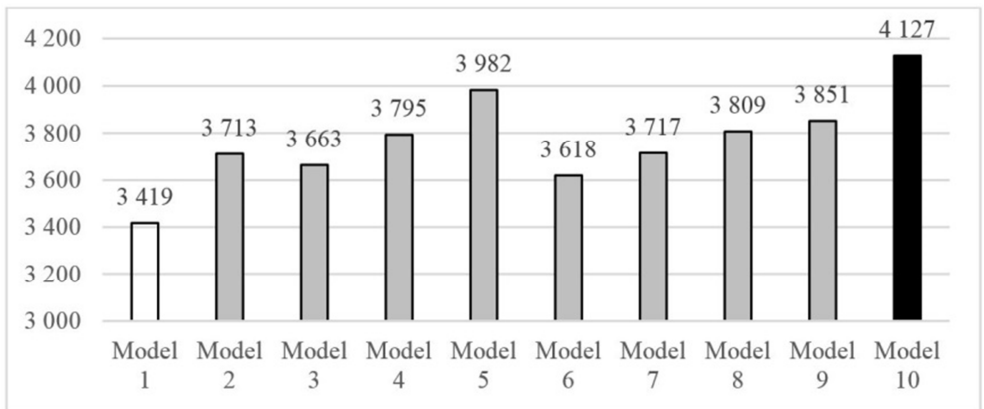

Fig. 3. Classified thermal comfort hours (category I and II) per year, according to EN 15251 and ISO 7730 in the sample room, Model 1 - Model 10 (IDA ICE 4.8)

The thermal comfort is improved by $8 \%$ using cantilever, while movable external blinds are less efficient (improvement only 6\%), fixed vertical lamellas are more advantageous (10\%), and finally, fixed horizontal louvres (14\%) reach best comfort compared to Model 1 (Fig. 3). The reference Model 1 and the model with best results (Model 5) were compared according to the operative temperature distribution (Fig. 4). The maximum peak temperature (temperature amplitudes) can be dimmed into category I. in Model 5 thanks to the fixed external horizontal lamella shield. In this case, there is continuous shading effect, hence it is disadvantageous in winter, both in terms of winter solar gain and all-year natural illumination. Therefore it is necessary to look into visual comfort as well (see section 5.2).

In general, it can be stated that the thermal comfort level of the south and southeast facing rooms is gradually improved by raising the parapet. Model 6 with $76 \%$ WWR 6\% improvement, Model 7 with 66.5\% WWR 8\% and Model 8 with 57\% WWR induced 10\% thermal comfort improvement compared to the Model 1 (Fig. 3). The best result was achieved with $120 \mathrm{~cm}$ high parapet, due to lowest WWR and solar loads, however, this is somewhat disadvantageous in winter due to the reduction of natural daylight and solar thermal gain. In terms of operative temperature, the results of Model 8 are approx. $1{ }^{\circ} \mathrm{C}$ lower as those of Model 1, keeping the thermal comfort in almost continuously below $26^{\circ} \mathrm{C}$ (Fig. 5).

Keeping the slab structures without suspended ceilings, enabled to release the heatstoring masses of the reinforced concrete slab structures from the 'thermal' covering. Due to the abandonment of the gypsum board ceiling, the results in the sample room 
show a $11 \%$ improvement over the reference Model 1 (Fig. 3). The high heat capacity of the slabs in Model 9 generated a more pleasant thermal comfort profile, dampening minimum and maximum amplitude peaks (Fig. 6). Apparently the same result was evolved with Model 5, which achieved the best thermal comfort in the sample room.

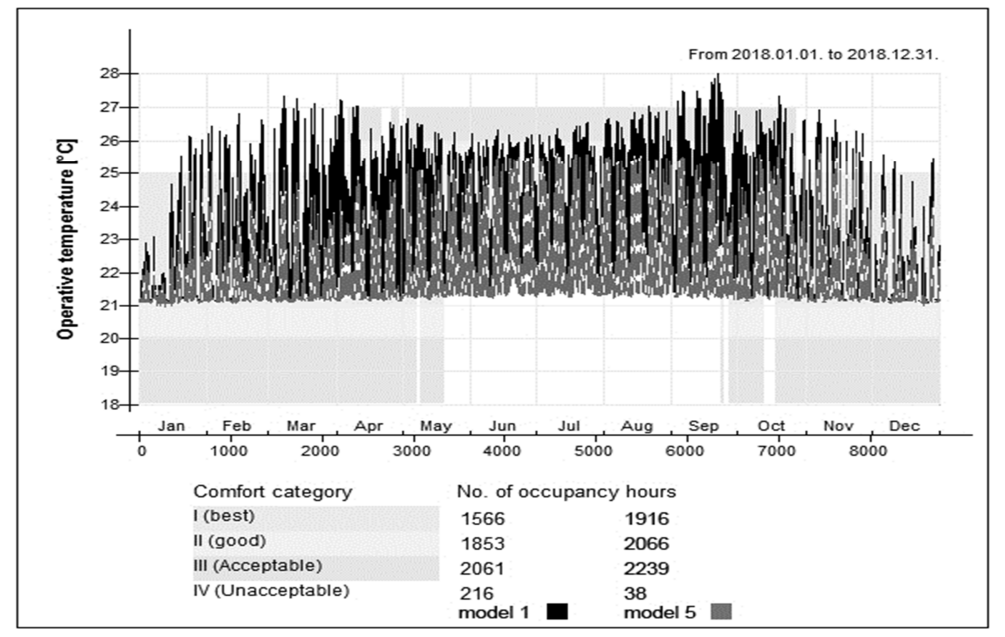

Fig. 4. Operative temperatures - thermal comfort hours according to EN 15251 and ISO 7730 in the sample room - Model 1 and Model 5 (IDA ICE 4.8)

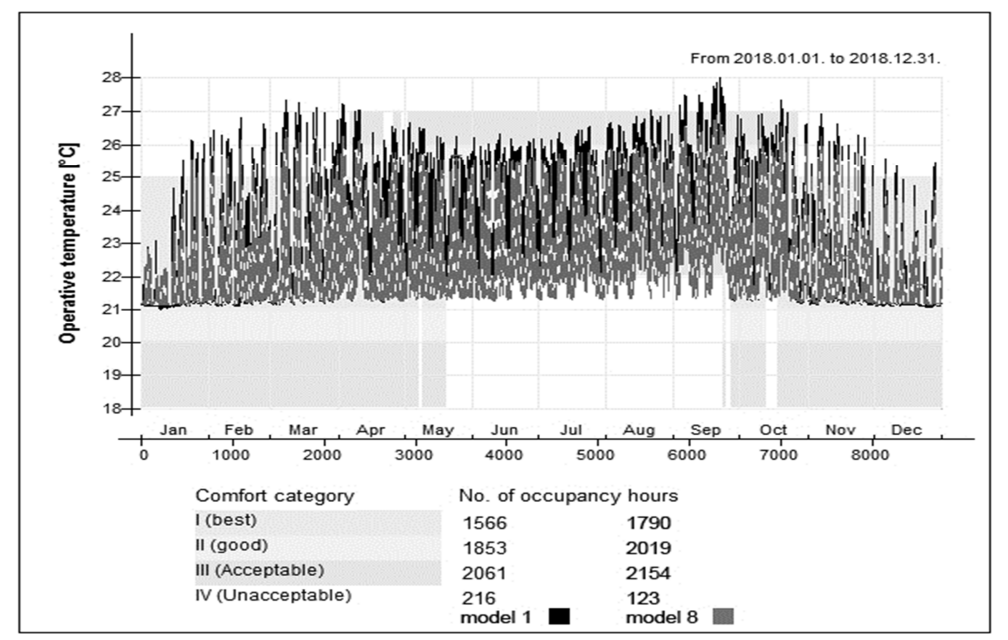

Fig. 5. Operative temperatures - thermal comfort hours according to EN 15251 and ISO 7730 in sample room - Model 1 and Model 8 (IDA ICE 4.8) 


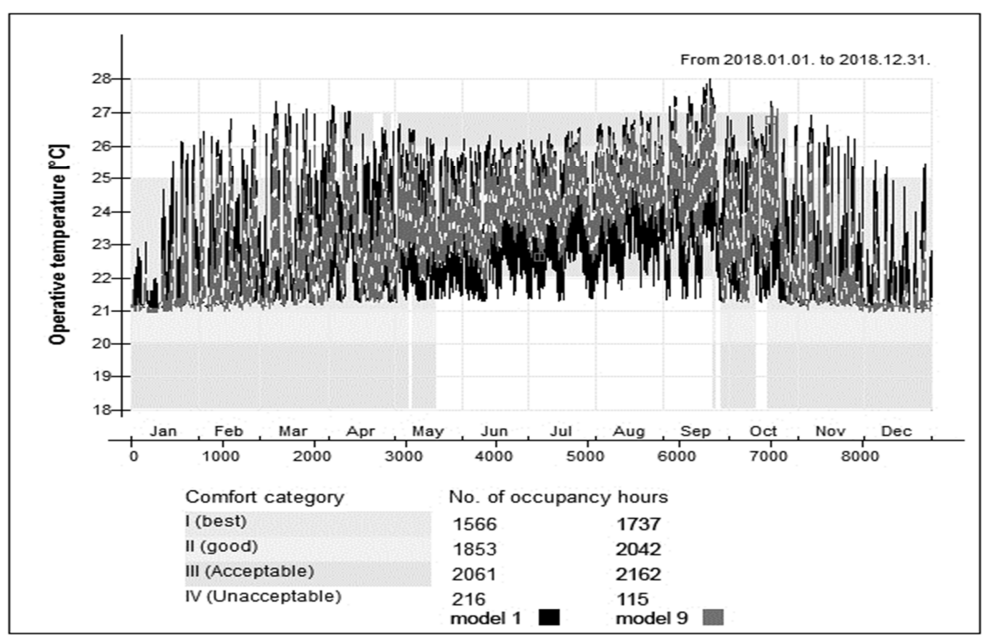

Fig. 6. Operative temperatures - thermal comfort hours according to EN 15251 and ISO 7730 in sample room - Model 1 and Model 9 (IDA ICE 4.8)

\subsection{Visual comfort}

In Fig. 7 the visual comfort performance was compared in case of Model 1 Model 10, in the sample room, by assessing the number of natural day lit hours over the level of 500 lx. Model 9 is not included as it does not affect the results by 'activating' the heat storage mass. The intensity of the natural daylight illumination has decreased gradually and significantly in dependency of the shading technology intensity. The more efficient the shading works, the more decrease of visually comfortable hours are achieved as follows: $-19 \%$ (Model 2), $-26 \%$ (Model 3) and $-37 \%$ (Model 4), finally $-51 \%$ (Model 5) compared to the reference Model 1. The mean illumination level in the visually comfortable time (hours with over 500 lx daylight intensity) changes according to the various shading technologies: the solar radiation controlled, moveable external blind system delivers highest illumination level (almost the same as without shading), while the remaining fixed shadings perform $16 \%$ and $19 \%$ lower illumination. The highest visual comfort was found in Model 6 among the 'parapet models'. The visual comfort has gradually declined in proportion to parapet elevation; Model 6 decreased the natural illumination duration over $500 \mathrm{~lx}$ by $9 \%$, Model 7 by $13 \%$ and Model 8 by $18 \%$ compared to Model 1.

\subsection{Optimal building envelope model proposal}

Considering the results of the previous case investigations, an 'ideal' Model 10 version was developed within the projects design boundaries, where WWR and 'activated' thermal mass (concreate slabs without suspended ceiling) was proposed. This decision is based on the weak daylight performance and high investment costs of the shading model versions, therefore a WWR (as a shading solution) is proposed with PH $90 \mathrm{~cm}$. The medium PH is marginally weaker than the PH $120 \mathrm{~cm}$ model, but this 
version represents functionally the most matching sloution to the office use. The 'activated' thermal mass improves thermal comfort additionally, by simultaneously not affecting the visual comfort. Hereinafter, the reference Model 1 and the building physics parameters of the considered new model are shown (Table I). The $10^{\text {th }}$ model is $17 \%$ stronger in the higher-class (I + II) thermal comfort hours (Fig. 3). This result reveals effects of the 'activation' of heat storage masses (cooling effect against overheating, thermal temperature amplitude reduction in the operative peak temperatures (Fig. 8), as well as the reduction of the glazing ratio from $20.9 \%$ to $17 \%$ for the whole building. In case of the sample room the WWR reduction goes from totally glazed (95\%) to $66.5 \%$ (reduction of summer heat load from solar radiation). The visual comfort in Model 10 is the same as in Model 7 (PH $90 \mathrm{~cm}$ ) because of the same model settings (Fig. 7).

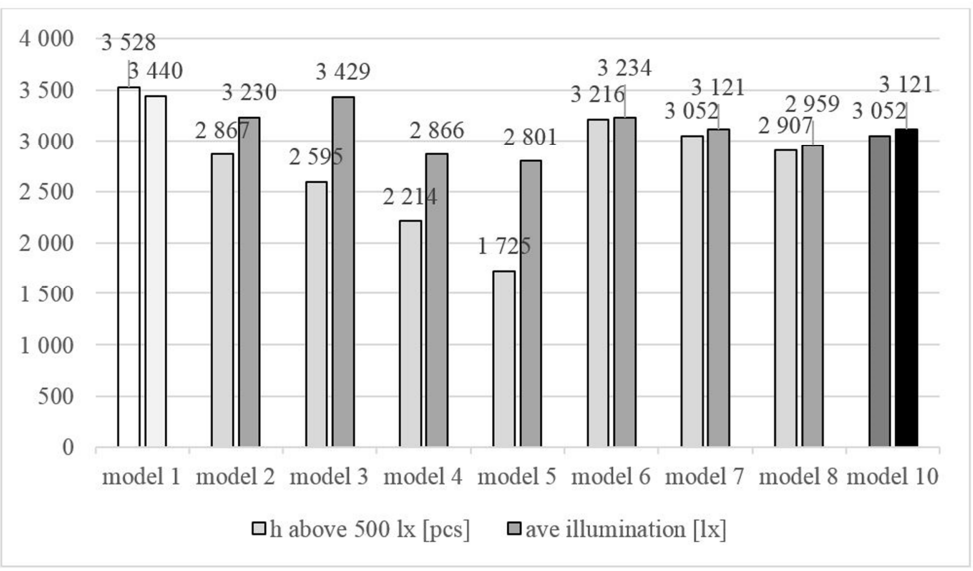

Fig. 7. Visual comfort, in the sample room (IDA ICE 4.8). Number of hours with daylight illumination intensity over $500 \mathrm{~lx}$, yearly mean illumination [lx]

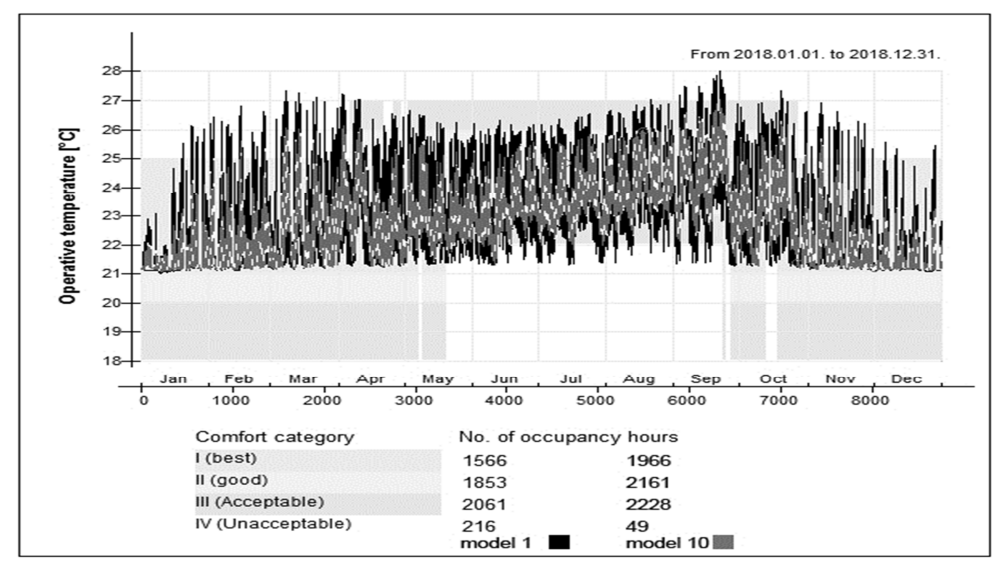

Fig. 8. Operative temperatures - thermal comfort hours according to EN 15251 and ISO 7730 in the sample room (IDA ICE 4.8) 


\section{Conclusions}

On the one hand, visual comfort suffers significantly, up to $51 \%$ less daylight performance due to increasing shading intensity (provided by external shading devices and reduced WWR in comparison to fully glazed facades, respectively), while thermal comfort increases up to $17 \%$. On the other hand, considering today's modern office environment with emerging use of information technologies, offices do not require high natural illumination intensity, hence the weaker illumination does not implicitly means disadvantage. Taking this into account, the thermal comfort considerations can yet justify external shading and/or reduced WWR solutions. However, regarding construction investment issues, the expensive external shading structures are negligible if the heat storage effect of reinforced concrete structures can be exerted by abandoning the suspended ceilings, and the wall-window ratio of the facades can be reduced as a cost effective shading solution. This finding has a positive side effect in the visual comfort performance, since the prevailing daylight illumination intensity remains significantly higher than as it is the case in shaded versions. As a result the optimized comfort model possesses PH $90 \mathrm{~cm}$ (reduced WWR) and abandoned suspended ceilings. To complete the building physics performance assessments, further studies are needed on used energy demand performance of the building envelope development investigations.

\section{Acknowledgements}

This research was carried out in the Energy Design Research Group, supported by the János Szentágothai Research Centre, University of Pécs.

\section{Open Access statement}

This is an open-access article distributed under the terms of the Creative Commons Attribution 4.0 International License (https://creativecommons.org/licenses/by/4.0/), which permits unrestricted use, distribution, and reproduction in any medium, provided the original author and source are credited, a link to the CC License is provided, and changes - if any - are indicated. (SID_1)

\section{References}

[1] Konis K., Gamas A., Kensek K. Passive performance and building form: An optimization framework for early-stage design support, Solar Energy, Vol. 125, 2016, pp. 161-179.

[2] Kheiri F. A review on optimization methods applied in energy-efficient building geometry and envelope design, Renewable and Sustainable Energy Reviews, Vol. 92, 2018, pp. 897-920.

[3] Bano F., Sehgal V. Finding the gaps and methodology of passive features of building envelope optimization and its requirement for office buildings in India, Thermal Science and Engineering Progress, Vol. 9, 2019, pp. 66-93. 
[4] Tian Z., Zhang X., Jin X., Zhou X., Si B., Shi X. Towards adoption of building energy simulation and optimization for passive building design: A survey and a review, Energy and Buildings, Vol. 158, 2018, pp. 1306-1316.

[5] Stevanović S. Optimization of passive solar design strategies: A review, Renewable and Sustainable Energy Reviews, Vol. 25, 2013, pp. 177-196.

[6] Prietoa A., Knaack U., Auer T., Klein T. Passive cooling \& climate responsive façade design: Exploring the limits of passive cooling strategies to improve the performance of commercial buildings in warm climates, Energy and Buildings, Vol. 175, 2018, pp. 30-47.

[7] Zhai Y., Wang Y., Huang Y., Meng X. A multi-objective optimization methodology for window design considering energy consumption, thermal environment and visual performance, Renewable Energy, Vol. 134, 2019, pp. 1190-1199.

[8] Kővári G., Kistelegdi I. Optimized building automation and control for the improvement of energy efficiency and climate comfort of office buildings, Pollack Periodica, Vol. 10, No. 1, 2015, pp. 71-82.

[9] Chen X., Yang H., Zhang W. Simulation-based approach to optimize passively designed buildings: A case study on a typical architectural form in hot and humid climates, Renewable and Sustainable Energy Reviews, Vol. 82, Part 2, 2018, pp. 1712-1725.

[10] Măgurean A. M. Case study of NZEB implementation into an early stage of the design phase for a new residential building, Procedia Manufacturing, Vol. 32, 2019, pp. 450-457.

[11] Ye Y., Hinkelman K., Zhang J., Zuo W., Wang G. A methodology to create prototypical building energy models for existing buildings: A case study on U.S. religious worship buildings, Energy and Buildings, Vol. 194, 2019, pp. 351-365.

[12] Wu W., Guo J., Li J., Hou H., Meng Q., Wang W. A multi-objective optimization design method in zero energy building study: A case study concerning small mass buildings in cold district of China, Energy and Buildings, Vol. 158, 2018, pp. 1613-1624.

[13] Ascione F., Borrelli M., De Masi R. F., de’ Rossi F., Vanoli G. P. Energy refurbishment of a university building in cold Italian backcountry, Part 1, Audit and calibration of the numerical model, Energy Procedia, Vol. 159, 2019, pp. 2-9.

[14] Ascione F., Borrelli M., De Masi R. F., de' Rossi F., Vanoli G. P. Energy refurbishment of a University building in cold Italian backcountry, Part 2, Sensitivity studies and optimization, Energy Procedia, Vol. 159, 2019, pp. 10-15.

[15] Radha C. H., Kistelegdi I. Thermal performance analysis of Sabunkaran Residential Building typology, Pollack Periodica, Vol. 12, 2017, pp. 151-162.

[16] How much energy do my household appliances use? https://www.energuide.be/ en/questions-answers/how-much-energy-do-my-household-appliances-use/71/, (last visited 28 May 2019).

[17] Kádár M. TSPC, Technical Supervision and Planning Consulting Hungary Ltd, Budapest, 2018. 